\title{
Research in halal logistics and halal supply chain: Issue and area development
}

\author{
Qurtubi $^{1{ }^{*}}$ and Elisa Kusrini ${ }^{2}$ \\ 1,2Department of Industrial Engineering, Universitas Islam Indonesia, Yogyakarta, Indonesia \\ ${ }^{1}$ Student of Post Graduate Program of Economics Faculty, Universitas Islam Indonesia, Yogyakarta, Indonesia
}

\begin{abstract}
Today the study of halal logistics and halal supply chain is growing and provides a great opportunity to do research both empirical and theoretical development. However, until now research in the field of logistic and supply chain is still limited. Therefore, this paper aims to explore opportunities and areas of development in this field by conducting literature review of previous research. Research opportunities in halal logistics and halal supply chain has been reviewed by many researchers and grouped into many categories, namely (1) Principles, Conceptual Model and Framework, (2) Innovation, Development and Challenges, (3) Critical Control Point, Critical Success Factors and Halal Control Activities, (4) Consumers Willingness to Pay, (5) Transportation and Information Technology, (6) Strategic approach. The issue in each category and research opportunities will be discussed in this paper.
\end{abstract}

\section{Introduction}

The development of the field of halal logistics and halal supply chain on all aspect of the halal business have provided great opportunities to do research. But as far as the author's knowledge, the paper discusses problems and research opportunities in the field of halal logistics and halal supply chain does not exist yet. While Jaafar et al. [5] only wrote the number of halal logistics and halal supply chain publications in the range of year 2004-2013. Therefore, this paper is expected to provide additional insight for researchers. Research opportunities in halal logistics and halal supply chain has been reviewed by many researchers. Principal component bodies (PCB) and the issues that related to halal logistics and halal supply chain consist of 6 issues. For detail of classification of each paper is showed on the Table 1 .

\section{Research Opportunities in Halal Logistics and Halal Supply Chain}

The halal logistics and halal supply chain issue can be classified into 6 categories, which includes: (1) Principles, Conceptual Model andFramework, (2) Innovation, Development and Challenges, (3) Critical Control Point, Critical Success Factors and Halal Control Activities, (4) Drivers of Consumers Willingness to Pay, (5) Transportation and Information Technology, (6) Strategic Approach. The following sections will explain each of the category.

\subsection{Principles, Conceptual Model and Framework}

A variety topics that fall into this category, such as Empirical Research, Qualitative Research, Different Markets, Good Manufacturing Practice (cGMP), Assesment Tools and Area Storage. Various areas of research opportunities based on the literature review include: Consumer perception of the Muslim consumer; Consumer perception Muslim and non-Muslim countries; Perception toward halal logistics; Testing the relationship between halal logistics, marketing mix, and the seven element, halal logistics market by performing SWOT analysis; The relationship between factors affecting the integrity of halal supply chain; Halal purchasing, halal network development, halal trade and halal parks; the application of halal in management of cosmetics and pharmaceutical supply chains; The management of halal ports; The principles in organising halal supply chains for different market (for example, between Muslim and nonMuslim countries); Integrate Good Manufacturing Practice (cGMP) and halal compliance into a holistic framework; Measuring of resilience impact of the attributes of halal logistics.

\subsection{Innovation, Development and Challenges}

The needs to be innovative in initiating more logistics services that are based on halal concept are crucial in meeting the needs of the increasing demand by the customers especially the Muslims [20]. Some issues are widely discussed in Innovation, Development and Challenges such as Halal Training Program and Research on Other Halal Business. Research opportunities in this area includes: Human capital training and development

\footnotetext{
*Corresponding author: qurtubi@uii.ac.id
} 
strategies and planning; Research on tourism, food product, pharmaceuticals, healthcare, cosmetics, and banking.

Table 1.Halal logistics and Halal Supply Chain Issue Classification

\begin{tabular}{|l|c|}
\hline \multicolumn{1}{|c|}{ Issue Classification } & Authors \\
\hline Principles, Conceptual Model and Framework & {$[1-15]$} \\
\hline Innovation, Development and Challenges & {$[16-21]$} \\
\hline $\begin{array}{l}\text { Critical Control Point, Critical Success Factors } \\
\text { and Halal Control Activities }\end{array}$ & {$[22-26]$} \\
\hline Consumers Willingness to Pay & {$[27-28]$} \\
\hline Transportation and Information Technology & {$[29-31]$} \\
\hline Strategic Approach & {$[32-34]$} \\
\hline
\end{tabular}

\subsection{Critical Control Point, Critical Success Factors \& Halal Control Activities}

A variety topics that fall into this category, such as Critical Control Point, Extra Cost, Empirical Evidence and Share the new knowledge and Techniques. Some research opportunities in this category such as Financial aspect of Halalan Toyyiban; Quantify of CSFs for a more exact outcome by clarifying with CSFs are applicable; Assist the smaller organizations toward the realization of halal supply chain.

\subsection{Consumer Willingness to Pay (WTP)}

Understanding consumer willingness to pay can lead manufacturers to implement the concept of halal in its value chain [27]. Some issues are widely discussed in Consumer Willingness to Pay include: Consumer Behavior and People's Concerns Regarding Halal. Some research opportunities in this area includes: Identifying a more appropriate method of measuring the long term effects of consumer behavior; Apply the research model to other countries.

\subsection{Transportation and Information Technology}

The Halaltracer tracking system was developed using the combinations of Global Positioning System (GPS) and geofence algorithm. The Halaltracer tracking system is significantly contributing in terms of automatic detection on the spatial activity taken during the halal product's shipment process [31]. Some issue that appear in the halal logistics and halal supply chain related to transportation and information technology such as: Adaption of Halal Supply Chain, Sensor and Improvement. Some research opportunities in this category such as: Finding what factors could be a driver for halal manufacturers; Research with better contextual adoption theory; Barcode sensor, QR code or RFID can be integrated in the system; Mobile version for tablet either in Android or IOS version.

\subsection{Strategic Approach}

Good governance requires the examination of external factors such as industry regulation, market forces and competition and internal factors such as business strategy and goals and corporate culture [33]. Some issues are widely discussed in Strategic Approach such as Halal Certification, SWOT analysis and Sample Size. Some research opportunities in this area are Develop a framework of halal certification; Find the barriers and critical success factors; SWOT analysis on other halal market (pharmaceutical and healthcare, tourism, and food products), Research with a larger sample size.

Various categories of issues and research opportunities are given in Table 2.

Table 2.Research opportunities in halal logistics and halal supply chain.

\begin{tabular}{|c|c|c|}
\hline Categories & Issue & $\begin{array}{c}\text { Development } \\
\text { areas/Research } \\
\text { opportunities }\end{array}$ \\
\hline $\begin{array}{l}\text { Principles, } \\
\text { Conceptual } \\
\text { Model and } \\
\text { Framework }\end{array}$ & $\begin{array}{l}\text { Empirical } \\
\text { research; } \\
\text { Qualitative } \\
\text { research; } \\
\text { Different } \\
\text { markets; } \\
\text { Good } \\
\text { Manufacturin } \\
\text { g Practice; } \\
\text { Assessment } \\
\text { tool; } \\
\text { Area of } \\
\text { storage. }\end{array}$ & $\begin{array}{l}\text { Consumer } \\
\text { perception of the } \\
\text { Muslim consumer } \\
\text { [2], } \\
\text { Consumer } \\
\text { perception Muslim } \\
\text { and non-Muslim } \\
\text { countries [4], } \\
\text { Perception toward } \\
\text { halal logistics [24], } \\
\text { Testing the } \\
\text { relationship between } \\
\text { halal logistics, } \\
\text { marketing mix and } \\
\text { the seven elements } \\
\text { [7], } \\
\text { Halal logistics } \\
\text { market by } \\
\text { performing SWOT } \\
\text { analysis [7], } \\
\text { The relationship } \\
\text { between factors } \\
\text { affecting the } \\
\text { integrity of halal } \\
\text { food supply chain } \\
\text { [8], } \\
\text { Halal purchasing, } \\
\text { halal network } \\
\text { development, halal } \\
\text { trade and halal parks } \\
\text { [11] }\end{array}$ \\
\hline $\begin{array}{l}\text { Innovation, } \\
\text { Development, } \\
\text { and Challenges }\end{array}$ & $\begin{array}{l}\text { Halal traning } \\
\text { program; } \\
\text { Research on } \\
\text { other halal } \\
\text { business. }\end{array}$ & $\begin{array}{l}\text { Human capital } \\
\text { training and } \\
\text { development } \\
\text { strategies and } \\
\text { planning [19], } \\
\text { Tourism, food } \\
\text { product, } \\
\text { pharmaceuticals, } \\
\text { healthcare, } \\
\text { cosmetics, bank } \\
{[16] .}\end{array}$ \\
\hline $\begin{array}{l}\text { Critical Control } \\
\text { Point, Critical }\end{array}$ & $\begin{array}{l}\text { Critical } \\
\text { Control Point; }\end{array}$ & \\
\hline
\end{tabular}




\begin{tabular}{|c|c|c|}
\hline $\begin{array}{l}\text { Success Factors } \\
\text { and Halal } \\
\text { Control } \\
\text { Activities }\end{array}$ & $\begin{array}{l}\text { Extra cost; } \\
\text { Empirical } \\
\text { evidence; } \\
\text { Share the new } \\
\text { knowledge } \\
\text { and } \\
\text { techniques. }\end{array}$ & $\begin{array}{l}\text { Financial aspectof } \\
\text { halalan toyyiban } \\
\text { supply chain [6], } \\
\text { Further research } \\
\text { could be embarked } \\
\text { in these areas [22], } \\
\text { Quantify the CSFs } \\
\text { for a more exact } \\
\text { outcome by } \\
\text { clarifying which } \\
\text { CSFs are applicable } \\
\text { [25], } \\
\text { Assist the smaller } \\
\text { organizations } \\
\text { towards the } \\
\text { realization of halal } \\
\text { supply chain [26]. }\end{array}$ \\
\hline $\begin{array}{l}\text { Consumers } \\
\text { Willingness to } \\
\text { Pay }\end{array}$ & $\begin{array}{l}\text { Consumer } \\
\text { behavior; } \\
\text { People's } \\
\text { concerns } \\
\text { regarding } \\
\text { halal. }\end{array}$ & $\begin{array}{l}\text { Identifying a more } \\
\text { appropriate method } \\
\text { of measuring the } \\
\text { long term effects of } \\
\text { consumer behavior } \\
\text { [27], } \\
\text { Apply the research } \\
\text { model to other } \\
\text { countries [28]. }\end{array}$ \\
\hline $\begin{array}{l}\text { Transportation } \\
\text { and Information } \\
\text { Technology }\end{array}$ & $\begin{array}{l}\text { Adoption of } \\
\text { halal supply } \\
\text { chain; } \\
\text { Sensor and } \\
\text { improvement. }\end{array}$ & $\begin{array}{l}\text { Finding what factors } \\
\text { could be a driver for } \\
\text { halal manufacturers } \\
{[30],} \\
\text { Research with better } \\
\text { contextual adoption } \\
\text { theory [30], } \\
\text { Barcode sensor, QR } \\
\text { code or RFID can be } \\
\text { integrated in the } \\
\text { system [31], } \\
\text { Mobile version for } \\
\text { tablet either } \\
\text { inAndroid or IOS } \\
\text { version [31]. }\end{array}$ \\
\hline $\begin{array}{l}\text { Strategic } \\
\text { Approach }\end{array}$ & $\begin{array}{l}\text { Halal } \\
\text { certification; } \\
\text { SWOT } \\
\text { analysis. }\end{array}$ & $\begin{array}{l}\text { Develop a } \\
\text { framework [33], } \\
\text { On other halal } \\
\text { markets such as } \\
\text { pharmaceutical and } \\
\text { healthcare, tourism, } \\
\text { and food products } \\
\text { [32], Finding the } \\
\text { barriers and critical } \\
\text { success factors [32]. }\end{array}$ \\
\hline
\end{tabular}

\section{Conclusion}

Today, the increasing competitiveness in industry force many company to increase capability in all aspect along their business. One of the challenges is to provide halal product and services that create opportunity for researcher to explore this filed. From study literature, it can be conclude that research in halal logistic and halal supply chain can be classified into 6 categories, namely Principles, Conceptual Model and Framework, Innovation, Development and Challenges, Critical Control Point, Critical Success Factors and Halal Control Activities, Consumers Willingness to Pay, Transportation and Information Technology, Strategic approach. The development of each categories still in early phase, therefore it provide great opportunity to study halal logistic and halal supply chain by considering the maturity of traditional logistic and supply chain.

\section{References}

1. E.N. Omar, H.S. Jaafar, IEEE Symp on Bus, Eng and Appl (ISBEIA) (2011)

2. M. Tieman, J. of Isl Mark 2, 186-195 (2011)

3. M. Tieman, J.G.A.J. van der Vost, M.C. Ghozali, J. of Isl Mark 3, 217-243 (2012)

4. M. Tieman, J. of Emerg Eco and Isl Res 1, 1 (2013)

5. H.S. Jaafar, E.N. Omar, M.R. Osman, Faisol N. Paper Presented at ICLT (2013)

6. E.N. Omar, H.S. Jaafar, M.R. Osman, J. of Emerg Eco and Isl Res 1, 3 (2013)

7. A.B.A. Hamid, M.S.A. Talib, N. Mohamad Intellectual Discourse 22, 191-214 (2014)

8. M.H. Zulfakar, M.M. Anuar, M.S.A. Talib, Proc-Soc and Beh Sci 121, 58-67 (2014)

9. E.N. Omar, H.S. Jaafar, M.R. Osman, J. of Emerg Eco and Isl Res 1, 3 (2013)

10. O. Aigbogun, Z. Ghazali, R. Razali, Glob Bus and Man Res: An Inter J. 7, 3 (2015)

11. M. Tieman, J. of Isl Mark 6, 2-21 (2015)

12. H.S. Jaafar, N. Faisol, F.A. Rahman, A. Muhammad, Sprin Sci+Bus Med (2016)

13. S.A. Rahim, B. Mohammad, N.A.A. Rahman, Sprin Sci+Bus Med (2016)

14. A. Asiaei, A.A. Aziz, S. Zailani, Sprin Sci+Bus Med (2016)

15. S. Nasir, H.S. Jaafar, Sci. Int(Lahore) 28(2), 17691774 (2016)

16. M.S.A. Talib, L. Rubin, V.K. Zhengyi, J. of Emerg Eco and Isl Res 1, 2 (2013)

17. N. Karia, M.H.A.H. Asaari, Vision 2020: Sust Growt, Eco Dev, and Glob Comp (2014)

18. M.H.A. Kadir, R.Z.R.M. Rasi, S.S. Omar, Z.I.A Manap, IOP Conf. Seri: Mat Sci and Eng 160, 012070 (2016)

19. H.I.C. Hasim, S.M.M. Shariff, Proc Eco and Fin 37, 33-38 (2016)

20. H.S. Jaafar, I.R. Endut, N. Faisol \& E.N. Omar, IMPRA Paper 34655, Posted 12 (2011)

21. N. Ahmad, S.M. Shariff, Proc Eco and Fin 37, 418425 (2016)

22.E.N. Omar, H.S. Jaafar, M.R. Osman, Proc-Soc and Beh Sci 00, 000-000 (2011)

23. R.C. Din, S. Daud, Proc-Soc and Beh Sci 121, 96-103 (2014)

24. M. Tieman, M.C. Ghazali, Proc-Soc and Beh Sci 121, 44-57 (2014)

25. M.S.A. Talib, A.B.A. Hamid, M.H. Zulfakar, J. of Isl Mark 6, 44-71 (2015) 
26. S.M. Shariff, H.S. Jaafar \& A. Muhammad. Sprin Sci+Bus Med (2016)

27. R. Kamaruddin, H. Iberahim, A. Shabudin, Proc-Soc and Beh Sci 50, 722-729 (2012)

28. E. Fathi, S. Zailani, M. Iranmanesh, K. Kanapathy, British Food J. 118, 464-479 (2016)

29. H.A. Tarmizi, N.H. Kamarulzaman, I.A. Latiff, A.A. Rahman, UMK Procedia 1, 42-49 (2014)

30. A.H. Ngah, Y. Zainuddin, R. Thurasamy R. Proc-Soc and Beh Sci 129, 388-395 (2014)
31. M.A. Mohamad, S. Mansor, N. Ahmad, W.A.W. Adnan, I.M. Wali, J. of Theori and Appl Inf Tech 90, 2 (2016)

32. M.S.A. Talib, A.B.A. Hamid, J. of Isl Mark 5, 3 (2014)

33. N. Noordin, N.L.M. Noor, Z. Samicho, Proc-Soc and Beh Sci 121, 79-95 (2014)

34. O. Aigbogun, Z. Ghazali, R. Razali, Int Rev of Man and Mark 6(S4), 209-216 (2016) 